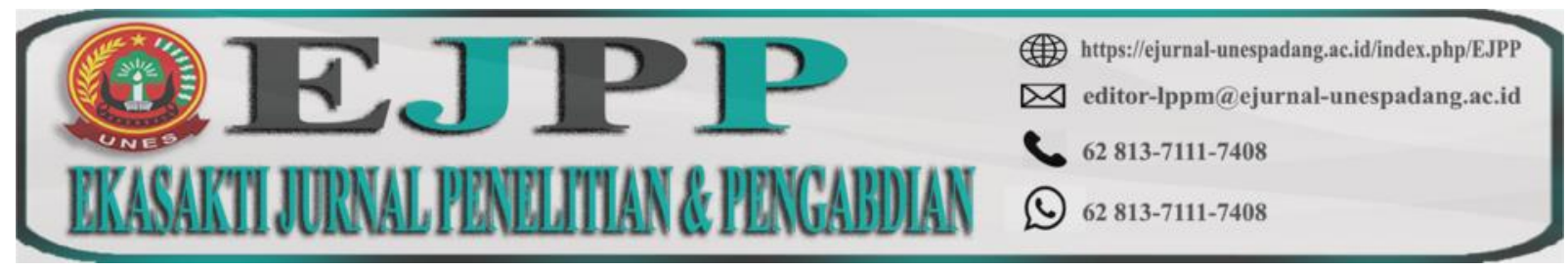

DOI: https://doi.org/10.31933/ejpp.v1i1

Received: 26/09/2020, Revised: 01/10/2020, Publish: 22/11/2020

\title{
ANALISIS LAPORAN ARUS KAS PADA DINAS KOMUNIKASI DAN INFORMATIKA KABUPATEN SOLOK TAHUN ANGGARAN 2019
}

\author{
Melli Herfina ${ }^{1}$, dan Hengky Saputra ${ }^{2}$ \\ 1) Program studi Akuntansi, Akademi Akuntansi Indonesia Padang. \\ Email: melliherfina@gmail.com \\ 2) Program studi Akuntansi, Akademi Akuntansi Indonesia Padang. \\ Email: hengkysaputra54@gmail.com
}

\begin{abstract}
ABSTRAK
Laporan arus kas adalah salah satu laporan keuangan yang digunakan oleh keluarga, perusahaan dan pemerintah, baik pemerintah daerah maupun pemerintah pusat, dimana laporan ini sangat berguna bagi pengguna laporan keuangan untuk memperolah gambaran tentang mutasi kas akibat dari aktivitas yang dilakukan. Penelitian ini bertujuan Untuk mengetahui apakah laporan arus kas pada Dinas Komunikasi dan Informatika Kabupaten Solok sudah berjalan dengan efektif dan untuk mengetahui kinerja Dinas Komunikasi dan Informatika Kabupaten Solok berdasarkan laporan arus kas. Metode analisis yang digunakan dalam penelitian ini adalah metode deskriptif. Dinas Komunikasi dan Informatika Kabupaten Solok sudah menyajikan laporan arus kas dengan baik dan efektif sesuai dengan Peraturan Pemerintah Nomor 24 Tahun 2005 tentang Standar Akuntansi Pemerintah dimana penyajian laporan tersebut sudah mencantumkan Laporan Realisasi Anggaran (LRA), Neraca, Laporan Arus Kas dan Catatan Atas Laporan Keuangan. Dari Catatan Atas Laporan Keuangan Dinas Komunikasi dan Informatika Tahun 2019, dapat disimpulkan bahwa kinerja Dinas Kominfo sudah berjalan dengan baik dengan pencapaian Pendapatan Asli Daerah (PAD) Dinas Kominfo mencapai angka yang lebih dari $100 \%$ dan secara umum sasaran-sasaran strategis yang ditetapkan dalam Rencana Kerja Tahunan Tahun 2019 telah dapat dipenuhi, meskipun rencana tersebut belum sepenuhnya tercapai $100 \%$.
\end{abstract}

Kata Kunci: Laporan arus kas, Standar Akuntansi Pemerintahan.

\begin{abstract}
The cash flow statement is one of the financial reports used by families, companies and governments, both local and central government, where this report is very useful for users of financial statements to obtain an overview of cash movements as a result of the activities carried out. This study aims to determine whether the cash flow statement at the Office of Communication and Information Technology in Solok Regency has been running effectively
\end{abstract}


and to determine the performance of the Office of Communication and Informatics in Solok Regency based on cash flow reports. The method of analysis used in this research is descriptive method. The Office of Communication and Information Technology of Solok Regency has presented cash flow reports properly and effectively in accordance with Government Regulation Number 24 of 2005 concerning Government Accounting Standards where the presentation of the report includes Budget Realization Report (LRA), Balance Sheet, Cash Flow Report and Notes to Financial Statements . From the Notes on the Financial Statements of the Communication and Information Technology Office for 2019, it can be concluded that the performance of the Communication and Information Service Office has been going well with the achievement of Regional Original Revenue (PAD) of the Kominfo Office reaching a figure of more than $100 \%$ and in general the strategic targets set out in the Plan. The 2019 Annual Work has been fulfilled, even though the plan has not been fully achieved $100 \%$.

\section{Keywords: Cash flow statement, Government accounting standards}

\section{PENDAHULUAN}

Laporan arus kas adalah salah satu laporan keuangan yang digunakan oleh keluarga, perusahaan dan pemerintah, baik pemerintah daerah maupun pemerintah pusat, dimana laporan ini sangat berguna bagi pengguna laporan keuangan untuk memperolah gambaran tentang mutasi kas akibat dari aktivitas yang dilakukan. Pada pemerintah daerah, aktivitas yang dimaksud adalah aktivitas operasi, aktivitas investasi non-keuangan, aktivitas pembiayaan dan aktivitas non-anggaran terhadap kondisi keuangan pemerintah daerah.

Laporan arus kas menggambarkan arus kas masuk dan arus kas keluar dan setara kas. Arus kas masuk dapat berasal dari penerimaan tunai pendapatan, penjualan aset tetap, pencairan dana cadangan, penjualan kekayaan daerah yang dipisahkan, pinjaman bahkan penerimaan atas potongan pembayaran yang dilakukan pemerintah. Sedangkan arus kas keluar dapat berupa pembayaran tunai belanja pegawai, belanja modal, belanja barang dan jasa, pembayaran cicilan hutang, pemberian pinjaman, pembentukan dana cadangan, dan penyetoran kepada pihak ketiga atas pemotongan yang telah dilakukan.

Melalui laporan arus kas, pengguna ataupun pembaca laporan dapat menilai kinerja finansial pemerintah daerah selama periode tertentu. Selain itu, laporan arus kas juga dapat digunakan untuk memprediksi kondisi keuangan di masa yang akan datang. Berdasarkan Pernyataan Standar Akuntansi Pemerintahan Nomor 03 Peraturan Pemerintah Nomor 71 Tahun 2010 dilakukannya pelaporan arus kas bertujuan untuk memberikan informasi mengenai sumber, penggunaan, perubahan kas dan setara kas selama suatu periode akuntansi serta saldo kas dan setara kas pada tanggal pelaporan.

Dengan dikeluarkannya Peraturan Pemerintah Nomor 105 Tahun 2000 tentang Pengelolaan dan Pertanggungjawaban Keuangan Daerah dan Peraturan Pemerintah Nomor 24 Tahun 2005 tentang Standar Akuntansi Pemerintahan, setiap pemerintah daerah diwajibkan menyusun laporan keuangan, antara lain Laporan Arus Kas. Laporan Arus Kas sangat penting untuk manajemen pemerintah daerah, bukan hanya untuk memenuhi kewajiban peraturan perundang- 
undangan yang berlaku, tetapi juga sebagai dasar untuk pengambilan keputusan yang terarah dalam rangka pengelolaan sumber daya ekonomi yang dimiliki oleh daerah secara efektif dan efisien.

Berbagai penelitian yang telah dilaksanakan dan diterbitkan dalam berbagai jurnal ataupun buku akuntansi, banyak yang membahas terkait analisis laporan arus kas. Berdasarkan latar belakang yang telah dikemukakan di atas, maka peneliti menganalisis lebih jauh tentang laporan arus kas pada Organisasi Perangkat Daerah (OPD) di Pemerintah Daerah khususnya pada Dinas Komunikasi dan Informatika Kabupaten Solok dengan judul penelitian "Analisis Laporan Arus Kas Pada Dinas Komunikasi dan Informatika Kabupaten Solok Tahun Anggaran 2019”.

Berdasarkan latar belakang di atas, penulis merumuskan permasalahan yang akan dibahas sebagai berikut :

1. Apakah laporan arus kas pada Dinas Komunikasi dan Informatika Kabupaten Solok sudah berjalan dengan efektif?

2. Bagaimana kinerja Dinas Komunikasi dan Informatika Kabupaten Solok berdasarkan laporan arus kas?

Adapun tujuan penelitian ini adalah sebagai berikut :

1. Untuk mengetahui apakah laporan arus kas pada Dinas Komunikasi dan Informatika Kabupaten Solok sudah berjalan dengan efektif.

2. Untuk mengetahui kinerja Dinas Komunikasi dan Informatika Kabupaten Solok berdasarkan laporan arus kas.

\section{METODE PENELITIAN}

\section{Metode Pengumpulan Data}

Studi kepustakaan merupakan penelitian dimana penulis mengumpulkan data dan informasi melalui sumber-sumber kepustakaan atau literature yang berkaitan dengan masalah yang diteliti. Studi ini dilakukan dengan membaca dan mengumpulkan data serta informasi melalui buku-buku, jurnal, penelitian terdahulu dan penelusuran di internet untuk mendapatkan data-data sekunder yang sesuai dengan permasalahan penelitian.

Studi lapangan yaitu suatu metode yang dilakukan oleh peneliti dengan cara pengamatan langsung terhadap kegiatan yang dilakukan oleh perusahaan. Pengumpulan data perusahaan diperoleh dari dokumen perusahaan. Data tersebut diperoleh langsung melalui wawancara dengan narasumber.

\section{Teknik Pengumpulan Data}

Peneliti melakukan wawancara dengan melakukan tanya jawab dengan Kasubag Perencanaan dan Keuangan Dinas Komunikasi dan Informatika terkait proses uang masuk dan uang keluar pada Dinas Komunikasi dan Informatika Kabupaten Solok. Teknik dokumentasi peneliti lakukan dengan cara mengumpulkan data dan dokumen-dokumen yang diperlukan dan berkaitan dengan laporan arus kas. 


\section{Jenis dan Sumber Data}

Jenis data yang digunakan dalam penelitian ini adalah data kualitatif dan data kuantitatif. Data kualitatif adalah data yang merupakan data bukan angka seperti sejarah berdirinya Dinas Komunikasi dan Informatika dan struktur organisasi dinas. Sedangkan data kuantitatif adalah data yang berupa kumpulan angka seperti laporan keuangan. Sumber data yang digunakan dalam penelitian ini adalah data primer dan data sekunder. Pengumpulan data primer berupa data yang diperoleh langsung dari Dinas Komunikasi dan Informatika Kabupaten Solok melalui wawancara dengan Kasubag Perencanaan dan Keuangan. Sedangkan data sekunder merupakan data dan informasi yang diperoleh dari sumber yang ada kaitannya dengan penelitian yang dilakukan penulis. Data sekunder terdiri dari sejarah Dinas dan struktur organisasi Dinas.

\section{Metode Analisis}

Metode analisis yang digunakan dalam penelitian ini adalah metode deskriptif. Menurut Sugiyono (2012:24), deskriptif adalah teknik yang menggolongkan, menganalisis, dan menginterpretasikan data yang diperoleh sehingga dapat memberikan gambaran yang jelas mengenai keadaan yang diteliti. Metode deskriptif adalah metode yang digunakan dengan cara mengumpulkan data laporan arus kas Dinas Komunikasi dan Informatika Kabupaten Solok tahun anggaran 2019.

\section{HASIL DAN PEMBAHASAN}

\section{Laporan Realisasi Anggaran (LRA) Pendapatan dan Belanja}

Tabel 1. Laporan Realisasi Anggaran (LRA) Pendapatan dan Belanja Dinas Kominfo Kabupaten Solok Sampai Dengan Tanggal 31 Desember 2019

\begin{tabular}{|c|c|c|c|c|}
\hline \multirow[b]{2}{*}{ No. } & \multirow[b]{2}{*}{ Uraian } & \multicolumn{2}{|c|}{ Jumlah (Rp) } & \multirow[b]{2}{*}{ Persentase (\%) } \\
\hline & & $\begin{array}{l}\text { Anggaran Setelah } \\
\text { Perubahan (Rp) }\end{array}$ & Realisasi (Rp) & \\
\hline 1 & 2 & 3 & 4 & $5=(4 / 3) * 100 \%$ \\
\hline \multirow[t]{3}{*}{1} & PENDAPATAN ASLI DAERAH & 500.000 .000 & 643.481 .068 & 128,7 \\
\hline & Retribusi Pengendalian Menara & & & \\
\hline & Telekomunikasi & 500.000 .000 & 643.481 .068 & 128,7 \\
\hline 2 & BELANJA & 6.068.244.878 & 5.831 .485 .040 & 96,10 \\
\hline 2.1 & Belanja Operasi & 5.429 .394 .878 & 5.195 .935 .318 & 95,70 \\
\hline \multirow[t]{6}{*}{ 2.1.1 } & Belanja Pegawai & 2.179.215.728 & 2.145.600.308 & 98,46 \\
\hline & Gaji dan Tunjangan & 1.219 .614 .728 & 1.220 .902 .067 & 100,11 \\
\hline & Tambahan Penghasilan PNS & 697.401 .000 & 675.568 .250 & 96,87 \\
\hline & Honorarium Non PNS & 247.200 .000 & 234.130 .000 & 94,71 \\
\hline & Insentif Pemungutan & & & \\
\hline & Menara & 15.000 .000 & 14.999 .991 & 100 \\
\hline \multirow[t]{3}{*}{ 2.1.2 } & Belanja Barang dan Jasa & 3.250 .179 .150 & 3.050.335.010 & $\mathbf{9 3 , 8 5}$ \\
\hline & Belanja Bahan Pakai Habis & 293.321 .150 & 271.004 .122 & 92.39 \\
\hline & Belanja Bahan/ Material & 11.500 .000 & 11.499 .700 & 100 \\
\hline
\end{tabular}




\begin{tabular}{|c|c|c|c|c|}
\hline \multirow[b]{2}{*}{ No. } & \multirow[b]{2}{*}{ Uraian } & \multicolumn{2}{|c|}{ Jumlah (Rp) } & \multirow[b]{2}{*}{ Persentase (\%) } \\
\hline & & $\begin{array}{l}\text { Anggaran Setelah } \\
\text { Perubahan (Rp) }\end{array}$ & Realisasi (Rp) & \\
\hline 1 & 2 & 3 & 4 & $5=(4 / 3) * 100 \%$ \\
\hline \multirow{10}{*}{2.2} & Belanja Jasa Kantor & 1.876 .037 .400 & 1.779 .949 .437 & 94,88 \\
\hline & Belanja Perawatan & & & \\
\hline & Bermotor & 58.500 .000 & 56.870 .000 & 97,21 \\
\hline & Belanja Cetak dan Penggandaan & 42.300 .000 & 39.657 .958 & 93,75 \\
\hline & Belanja Makanan dan Minuman & 54.000 .000 & 47.146 .300 & 87,31 \\
\hline & Belanja Perjalanan Dinas & 789.820 .600 & 735.264 .493 & 93,09 \\
\hline & Belanja Pemeliharaan & 62.050 .000 & 57.343 .000 & 92,41 \\
\hline & Honorarium PNS/ Non PNS & 62.650 .000 & 51.600 .000 & 82,36 \\
\hline & Belanja Modal & 638.850 .000 & 635.549.722 & 99,64 \\
\hline & Belanja Modal Peralatan dan & & & \\
\hline \multirow[t]{8}{*}{ 2.2.1 } & Mesin & 593.850 .000 & 590.762 .172 & 92,47 \\
\hline & $\begin{array}{l}\text { Belanja Modal Pengadaan Alat-Alat } \\
\text { Bantu Keria }\end{array}$ & 205550000 & 303301047 & 0801 \\
\hline & Belanja Modal Pengadaan Peralatan & 205.530 .000 & 205.501 .941 & 90,91 \\
\hline & $\begin{array}{l}\text { dan Perlengkapan Kantor/ Rumah } \\
\text { Tangga }\end{array}$ & 222.850 .000 & 222.664 .919 & 99,92 \\
\hline & Belanja Modal Pengadaan Komputer/ & & & \\
\hline & Printer dan Perlengkapannya & 111.450 .000 & 111.345 .520 & 99,91 \\
\hline & Belanja Modal Pengadaan Alat-Alat & & & \\
\hline & Studio & 54.000 .000 & 53.449 .786 & 98,98 \\
\hline \multirow[t]{4}{*}{2.2 .2} & Belanja Jalan, Irigasi dan Jaringan & 45.000 .000 & 44.787.550 & $\mathbf{9 9 , 5 3}$ \\
\hline & Belanja Modal Pengadaan Jaringan & 45.000 .000 & 44.787 .550 & 99,53 \\
\hline & Jumlah & 6.068.244.878 & 5.831 .485 .040 & 96,10 \\
\hline & Surplus / Defisit & $(5.568 .244 .878)$ & (5.188.003.972) & \\
\hline
\end{tabular}

Sumber : Laporan Realisasi Anggaran (LRA) Pendapatan dan Belanja Dinas Kominfo Kabupaten Solok Tahun Anggaran 2019

Pendapatan Asli Daerah (PAD) Dinas Kominfo

Tabel 2. Pendapatan Asli Daerah (PAD) Dinas Kominfo Tahun 2019

\begin{tabular}{|c|c|c|c|c|}
\hline \multirow{2}{*}{ No. } & \multirow{2}{*}{ Uraian } & \multicolumn{2}{|c|}{ Jumlah (Rp) } & \multirow{2}{*}{ Persentase $(\%)$} \\
\hline & & Target (Rp) & Realisasi (Rp) & \\
\hline 1 & 2 & 3 & 4 & $5=(4 / 3) * 100 \%$ \\
\hline \multirow[t]{3}{*}{1} & PENDAPATAN ASLI DAERAH & 500.000 .000 & 643.481.068 & 128,7 \\
\hline & Pendapatan Retribusi Daerah & 500.000 .000 & 643.481 .068 & 128,7 \\
\hline & Jumlah & 500.000 .000 & 643.481 .068 & 128,7 \\
\hline
\end{tabular}

Sumber : Laporan Keuangan Dinas Kominfo Kabupaten Solok Tahun 2019

Dari tabel di atas dapat dilihat realisasi tersebut mencapai angka 128,7 \% dari target yang diberikan. PAD pada Dinas Kominfo diperoleh dari Retribusi Pengendalian Menara Telekomunikasi yang ada di Kabupaten Solok.

\section{Belanja Dinas Kominfo}

Belanja Dinas Kominfo Kabupaten Solok terdiri dari Belanja Operasi dan Belanja Modal. Belanja Operasi terdiri dari Belanja Pegawai dan Belanja Barang dan Jasa. Sedangkan Belanja 
Modal terdiri dari Belanja Modal Peralatan dan Mesin serta Belanja Modal Jalan, Irigasi dan Jaringan. Rincian belanja tersebut dapat dilihat pada tabel berikut :

\section{Laporan Realisasi Anggaran (LRA) Pendapatan dan Belanja}

Tabel 3. Laporan Realisasi Anggaran (LRA) Pendapatan dan Belanja Dinas Kominfo Kabupaten Solok Sampai Dengan Tanggal 31 Desember 2019

\begin{tabular}{|c|c|c|c|c|}
\hline \multirow[b]{2}{*}{ No. } & \multirow[b]{2}{*}{ Uraian } & \multicolumn{2}{|c|}{ Jumlah (Rp) } & \multirow[b]{2}{*}{ Persentase $(\%)$} \\
\hline & & $\begin{array}{c}\text { Anggaran } \\
\text { Setelah } \\
\text { Perubahan (Rp) }\end{array}$ & Realisasi (Rp) & \\
\hline 1 & 2 & 3 & 4 & $5=(4 / 3) * 100 \%$ \\
\hline \multirow[t]{3}{*}{1} & PENDAPATAN ASLI DAERAH & 500.000 .000 & 643.481 .068 & 128,7 \\
\hline & Retribusi Pengendalian Menara & & & \\
\hline & Telekomunikasi & 500.000 .000 & 643.481 .068 & 128,7 \\
\hline 2 & BELANJA & 6.068.244.878 & 5.831 .485 .040 & 96,10 \\
\hline 2.1 & Belanja Operasi & 5.429.394.878 & 5.195.935.318 & 95,70 \\
\hline \multirow[t]{5}{*}{ 2.1.1 } & Belanja Pegawai & 2.179.215.728 & 2.145.600.308 & 98,46 \\
\hline & Gaji dan Tunjangan & 1.219.614.728 & 1.220 .902 .067 & 100,11 \\
\hline & Tambahan Penghasilan PNS & 697.401 .000 & 675.568 .250 & 96,87 \\
\hline & Honorarium Non PNS & 247.200 .000 & 234.130 .000 & 94,71 \\
\hline & Insentif Pemungutan Retribusi Menara & 15.000 .000 & 14.999.991 & 100 \\
\hline \multirow[t]{10}{*}{ 2.1.2 } & - Belanja Barang dan Jasa & 3.250.179.150 & 3.050.335.010 & $\mathbf{9 3 , 8 5}$ \\
\hline & Belanja Bahan Pakai Habis & 293.321 .150 & 271.004 .122 & 92.39 \\
\hline & Belanja Bahan/ Material & 11.500 .000 & 11.499 .700 & 100 \\
\hline & Belanja Jasa Kantor & 1.876 .037 .400 & 1.779 .949 .437 & 94,88 \\
\hline & Belanja Perawatan Kendaraan Bermotor & 58.500 .000 & 56.870 .000 & 97,21 \\
\hline & Belanja Cetak dan Penggandaan & 42.300 .000 & 39.657 .958 & 93,75 \\
\hline & Belanja Makanan dan Minuman & 54.000 .000 & 47.146 .300 & 87,31 \\
\hline & Belanja Perjalanan Dinas & 789.820 .600 & 735.264 .493 & 93,09 \\
\hline & Belanja Pemeliharaan & 62.050 .000 & 57.343 .000 & 92,41 \\
\hline & Honorarium PNS/ Non PNS & 62.650 .000 & 51.600 .000 & 82,36 \\
\hline 2.2 & Belanja Modal & 638.850 .000 & 635.549 .722 & 99,64 \\
\hline \multirow[t]{9}{*}{ 2.2.1 } & Belanja Modal Peralatan dan Mesin & 593.850 .000 & 590.762 .172 & 92,47 \\
\hline & Belanja Modal Pengadaan Alat-Alat & & & \\
\hline & Bantu Kerja & 205.550 .000 & 203.301 .947 & 98,91 \\
\hline & Belanja Modal Pengadaan Peralatan dan & & & \\
\hline & Perlengkapan Kantor/ Rumah Tangga & 222.850 .000 & 222.664 .919 & 99,92 \\
\hline & Belanja Modal Pengadaan Komputer/ & & & \\
\hline & Printer dan Perlengkapannya & 111.450 .000 & 111.345 .520 & 99,91 \\
\hline & Belanja Modal Pengadaan Alat-Alat & & & \\
\hline & Studio & 54.000 .000 & 53.449 .786 & 98,98 \\
\hline \multirow[t]{4}{*}{ 2.2.2 } & Belanja Jalan, Irigasi dan Jaringan & 45.000 .000 & 44.787.550 & $\mathbf{9 9 , 5 3}$ \\
\hline & Belanja Modal Pengadaan Jaringan & 45.000 .000 & 44.787 .550 & 99,53 \\
\hline & Jumlah & 6.068.244.878 & 5.831 .485 .040 & 96,10 \\
\hline & Surplus / Defisit & $(5.568 .244 .878)$ & (5.188.003.972) & \\
\hline
\end{tabular}

Sumber : Laporan Realisasi Anggaran (LRA) Pendapatan dan Belanja Dinas Kominfo Kabupaten Solok Tahun Anggaran 2019 
Pendapatan Asli Daerah (PAD) Dinas Kominfo

Tabel 4. Pendapatan Asli Daerah (PAD) Dinas Kominfo Tahun 2019

\begin{tabular}{|c|c|c|c|c|}
\hline \multirow[b]{2}{*}{ No. } & \multirow[b]{2}{*}{ Uraian } & \multicolumn{2}{|c|}{ Jumlah (Rp) } & \multirow[b]{2}{*}{ Persentase $(\%)$} \\
\hline & & Target (Rp) & Realisasi (Rp) & \\
\hline 1 & 2 & 3 & 4 & $5=(4 / 3) * 100 \%$ \\
\hline 1 & $\begin{array}{l}\text { PENDAPATAN ASLI DAERAH } \\
\text { Pendapatan Retribusi Daerah }\end{array}$ & $\begin{array}{l}\mathbf{5 0 0 . 0 0 0 . 0 0 0} \\
500.000 .000\end{array}$ & $\begin{array}{l}\mathbf{6 4 3 . 4 8 1 . 0 6 8} \\
643.481 .068\end{array}$ & $\begin{array}{r}\mathbf{1 2 8 , 7} \\
128,7\end{array}$ \\
\hline & Jumlah & 500.000 .000 & 643.481 .068 & 128,7 \\
\hline
\end{tabular}

Sumber : Laporan Keuangan Dinas Kominfo Kabupaten Solok Tahun 2019

Dari tabel di atas dapat dilihat bahwa pendapatan asli daerah (PAD) pada Dinas Kominfo sebesar Rp. 643.481.068,-. Dimana realisasi tersebut mencapai angka 128,7 \% dari target yang diberikan. PAD pada Dinas Kominfo diperoleh dari Retribusi Pengendalian Menara Telekomunikasi yang ada di Kabupaten Solok.

\section{Belanja Dinas Kominfo}

Belanja Dinas Kominfo Kabupaten Solok terdiri dari Belanja Operasi dan Belanja Modal. Belanja Operasi terdiri dari Belanja Pegawai dan Belanja Barang dan Jasa. Sedangkan Belanja Modal terdiri dari Belanja Modal Peralatan dan Mesin serta Belanja Modal Jalan, Irigasi dan Jaringan. Rincian belanja tersebut dapat dilihat pada tabel berikut :

Tabel 5. Belanja Dinas Kominfo Tahun 2019

\begin{tabular}{|c|c|c|c|c|}
\hline \multirow[b]{2}{*}{ No. } & \multirow[b]{2}{*}{ Uraian } & \multicolumn{2}{|c|}{ Jumlah (Rp) } & \multirow[b]{2}{*}{ Persentase $(\%)$} \\
\hline & & $\begin{array}{l}\text { Anggaran Setelah } \\
\text { Perubahan (Rp) }\end{array}$ & Realisasi (Rp) & \\
\hline 1 & 2 & 3 & 4 & $5=(4 / 3) * 100 \%$ \\
\hline & BELANJA & 6.068.244.878 & 5.831 .485 .040 & 96,10 \\
\hline & Belanja Operasi & 5.429.394.878 & 5.195.935.318 & 95,70 \\
\hline & Belanja Pegawai & 2.179.215.728 & 2.145.600.308 & 98,46 \\
\hline & Belanja Barang dan Jasa & 3.250 .179 .150 & 3.050 .335 .010 & 93,85 \\
\hline & Belanja Modal & 638.850 .000 & 635.549.722 & 99,64 \\
\hline & Belanja Modal Peralatan dan Mesin & 593.850 .000 & 590.762 .172 & 92,47 \\
\hline & Belanja Jalan, Irigasi dan Jaringan & 45.000 .000 & 44.787 .550 & 99,53 \\
\hline & Jumlah & 6.068.244.878 & 5.831 .485 .040 & 96,10 \\
\hline & Surplus / Defisit & $(5.568 .244 .878)$ & (5.188.003.972) & \\
\hline
\end{tabular}

Sumber : Laporan Keuangan Dinas Kominfo Kabupaten Solok Tahun 2019

Dari tabel di atas dapat dilihat bahwa pada Dinas Komunikasi dan Informatika Kabupaten Solok laporan arus kas disajikan berdasarkan aktivitas operasi dan aktivitas investasi asset non keuangan. 


\section{Laporan Arus Kas Dinas Kominfo}

Tabel 6. Laporan Arus Kas Dinas Kominfo Kabupaten Solok Tahun Anggaran 2019

\begin{tabular}{|c|c|c|c|c|}
\hline \multirow{2}{*}{ NO } & \multirow{2}{*}{ URAIAN } & \multicolumn{2}{|c|}{ JUMLAH } & \multirow{2}{*}{$\begin{array}{c}\text { PERSENTASE } \\
(\%)\end{array}$} \\
\hline & & ANGGARAN (Rp) & REALISASI (Rp) & \\
\hline \multirow[t]{3}{*}{1} & Arus Kas Masuk dari Aktivitas Operas & & & \\
\hline & Pendapatan Retribusi Daerah & 500.000 .000 & 643.481 .068 & 128,7 \\
\hline & Jumlah Arus Kas Masuk & 500.000 .000 & 643.481 .068 & 128,7 \\
\hline \multirow[t]{3}{*}{2} & Arus Kas Keluar dari Aktivitas Operas & & & \\
\hline & Belanja Pegawai & 2.179.215.728 & 2.145 .600 .308 & 98,46 \\
\hline & Belanja Barang dan Jasa & 3.250 .179 .150 & 3.050.335.010 & 93,85 \\
\hline \multirow[t]{4}{*}{3} & Arus Kas Keluar dari Aktivitas Aset No & Ton Keuangan & & \\
\hline & Belanja Modal Peralatan dan Mesin & 593.850 .000 & 590.762 .172 & 92,47 \\
\hline & Belanja Jalan, Irigasi dan Jaringan & 45.000 .000 & 44.787 .550 & 99,53 \\
\hline & Jumlah Arus Kas Keluar & 6.068 .244 .878 & 5.831 .485 .040 & 96,10 \\
\hline
\end{tabular}

\section{Belanja Operasi}

Belanja Operasi merupakan belanja yang dianggarkan untuk kegiatan sehari-hari Pemerintah Daerah yang memberi manfaat jangka pendek (belanja pegawai dan belanja barang dan jasa). Belanja Operasi terdiri dari Belanja Pegawai dan Belanja Barang dan Jasa. Dari tabel di atas dapat dirumuskan sebagai berikut :

$$
\begin{gathered}
\text { Persentase Belanja Pegawai }=\frac{2.145 .600 .308}{2.179 .215 .728} \times 100 \%=98,46 \% \\
\text { Persentase Belanja Barang dan Jasa }=\frac{3.050 .335 .010}{3.250 .179 .150} \times 100 \% \\
=93,85 \%
\end{gathered}
$$

Dari kalkulasi di atas dapat dilihat bahwa belanja pegawai pada tahun 2019 terealisasi sebesar 98,46\% dab belanja barang dan jasa teralisasi 93,85\%. Secara keseluruhan belanja operasi terealisasi sebesar $95,70 \%$.

\section{Belanja Modal}

Pada tahun 2019 belanja modal dinas Kominfo dianggarkan sebesar Rp. 638.850.000 yang terdiri dari belanja modal peralatan dan mesin serta belanja modal jalan, irigasi dan jaringan.

$$
\begin{aligned}
& \text { Belanja Modal Peralatan dan Mesin }=\frac{590.762 .172}{593.850 .000} \times 100 \%=99,48 \% \\
& \text { Belanja Modal Jalan, Irigasi dan Jaringan }=\frac{44.787 .550}{45.000 .000} \times 100 \%=99,53 \%
\end{aligned}
$$

Belanja modal peralatan dan mesin dianggarkan sebesar Rp. 593.850.000 dan terealisasi sebesar Rp. 590.762.172. Nilai realisasi tersebut setara dengan 99,48\%. Sedangkan belanja modal jalan, irigasi da jaringan dianggarkan sebesar Rp. 45.000 .000 dan terealisasi sebesar Rp. 44.787.550 dengan persentase $99,53 \%$. 
Tabel 7. Belanja Dinas Kominfo Tahun 2019

\begin{tabular}{|c|c|c|c|c|}
\hline \multirow[b]{2}{*}{ No. } & \multirow[b]{2}{*}{ Uraian } & \multicolumn{2}{|c|}{ Jumlah (Rp) } & \multirow[b]{2}{*}{ Persentase $(\%)$} \\
\hline & & $\begin{array}{l}\text { Anggaran Setelah } \\
\text { Perubahan (Rp) }\end{array}$ & Realisasi (Rp) & \\
\hline 1 & 2 & 3 & 4 & $5=(4 / 3) * 100 \%$ \\
\hline & BELANJA & 6.068.244.878 & 5.831 .485 .040 & 96,10 \\
\hline & Belanja Operasi & 5.429.394.878 & 5.195 .935 .318 & 95,70 \\
\hline & - Belanja Pegawai & 2.179.215.728 & 2.145.600.308 & 98,46 \\
\hline & - Belanja Barang dan Jasa & 3.250 .179 .150 & 3.050 .335 .010 & 93,85 \\
\hline & Belanja Modal & 638.850.000 & 635.549.722 & 99,64 \\
\hline & - Belanja Modal Peralatan dan & & & \\
\hline & Mesin & 593.850 .000 & 590.762 .172 & 92,47 \\
\hline & - Belanja Jalan, Irigasi dan Jaringan & 45.000 .000 & 44.787 .550 & 99,53 \\
\hline & Jumlah & 6.068.244.878 & 5.831 .485 .040 & 96,10 \\
\hline & Surplus / Defisit & (5.568.244.878) & (5.188.003.972) & \\
\hline
\end{tabular}

Sumber : Laporan Keuangan Dinas Kominfo Kabupaten Solok Tahun 2019

Dari tabel di atas dapat dilihat bahwa pada Dinas Komunikasi dan Informatika Kabupaten Solok laporan arus kas disajikan berdasarkan aktivitas operasi dan aktivitas investasi asset non keuangan.

\section{Laporan Arus Kas Dinas Kominfo}

Tabel 8. Laporan Arus Kas Dinas Kominfo Kabupaten Solok Tahun Anggaran 2019

\begin{tabular}{|c|c|c|c|c|}
\hline \multirow[b]{2}{*}{ NO } & \multirow[b]{2}{*}{ URAIAN } & \multicolumn{2}{|c|}{ JUMLAH } & \multirow[b]{2}{*}{$\begin{array}{c}\text { PERSENTASE } \\
(\%)\end{array}$} \\
\hline & & $\begin{array}{l}\text { ANGGARAN } \\
\text { (Rp) }\end{array}$ & $\begin{array}{l}\text { REALISASI } \\
\text { (Rp) }\end{array}$ & \\
\hline \multirow[t]{3}{*}{1} & Arus Kas Masuk dari Aktivitas Operasi & & & \\
\hline & Pendapatan Retribusi Daerah & 500.000 .000 & 643.481 .068 & 128,7 \\
\hline & Jumlah Arus Kas Masuk & 500.000 .000 & 643.481 .068 & 128,7 \\
\hline \multirow[t]{3}{*}{2} & Arus Kas Keluar dari Aktivitas Operasi & & & \\
\hline & Belanja Pegawai & 2.179 .215 .728 & 2.145 .600 .308 & 98,46 \\
\hline & Belanja Barang dan Jasa & 3.250 .179 .150 & 3.050 .335 .010 & 93,85 \\
\hline \multirow[t]{4}{*}{3} & Arus Kas Keluar dari Aktivitas Aset Non & gan & & \\
\hline & Belanja Modal Peralatan dan Mesin & 593.850 .000 & 590.762 .172 & 92,47 \\
\hline & Belanja Jalan, Irigasi dan Jaringan & 45.000 .000 & 44.787 .550 & 99,53 \\
\hline & Jumlah Arus Kas Keluar & 6.068 .244 .878 & 5.831 .485 .040 & 96,10 \\
\hline
\end{tabular}

\section{Belanja Operasi}

Belanja Operasi merupakan belanja yang dianggarkan untuk kegiatan sehari-hari Pemerintah Daerah yang memberi manfaat jangka pendek (belanja pegawai dan belanja barang dan jasa). Belanja Operasi terdiri dari Belanja Pegawai dan Belanja Barang dan Jasa. Dari tabel di atas dapat dirumuskan sebagai berikut :

$$
\text { Persentase Belanja Pegawai }=\frac{2 \cdot 145.600 .308}{2 \cdot 179.215 .728} \times 100 \%=98,46 \%
$$




$$
\begin{aligned}
\text { Persentase Belanja Barang dan Jasa } & =\frac{3.050 .335 .010}{3.250 .179 .150} \times 100 \% \\
& =93,85 \%
\end{aligned}
$$

Dari kalkulasi di atas dapat dilihat bahwa belanja pegawai pada tahun 2019 terealisasi sebesar 98,46\% dab belanja barang dan jasa teralisasi 93,85\%. Secara keseluruhan belanja operasi terealisasi sebesar $95,70 \%$.

\section{Belanja Modal}

Pada tahun 2019 belanja modal dinas Kominfo dianggarkan sebesar Rp. 638.850.000 yang terdiri dari belanja modal peralatan dan mesin serta belanja modal jalan, irigasi dan jaringan.

$$
\begin{gathered}
\text { Belanja Modal Peralatan dan Mesin }=\frac{590.762 .172}{593.850 .000} \times 100 \%=99,48 \% \\
\text { Belanja Modal Jalan, Irigasi dan Jaringan }=\frac{44.787 .550}{45.000 .000} \times 100 \%=99,53 \%
\end{gathered}
$$

Belanja modal peralatan dan mesin dianggarkan sebesar Rp. 593.850 .000 dan terealisasi sebesar Rp. 590.762.172. Nilai realisasi tersebut setara dengan 99,48\%. Sedangkan belanja modal jalan, irigasi da jaringan dianggarkan sebesar Rp. 45.000 .000 dan terealisasi sebesar Rp.

\begin{tabular}{|c|c|c|c|}
\hline \multicolumn{4}{|c|}{$\begin{array}{c}\text { PEMERINTAH KABUPATEN SOLOK } \\
\text { NERACA DINAS KOMUNIKASI DAN INFORMATIKA } \\
\text { KABUPATEN SOLOK } \\
\text { Per } 31 \text { Desember Tahun } 2019 \text { dan Tahun } 2018\end{array}$} \\
\hline \multirow[t]{2}{*}{ Uraian } & \multicolumn{2}{|c|}{ Jumlah (Rp) } & \multirow{2}{*}{$\begin{array}{l}\text { Penambahan/ } \\
\text { Pengurangan }\end{array}$} \\
\hline & 2019 & 2018 & \\
\hline ASET & $1.465 .503 .618,97$ & 715.194.964,77 & $750.308 .654,20$ \\
\hline ASET LANCAR & $925.500,00$ & $3.537 .000,00$ & $(2.611 .500,00)$ \\
\hline Persediaan & $925.500,00$ & $3.537 .000,00$ & $(2.611 .500,00)$ \\
\hline $\begin{array}{l}\text { Persediaan bahan Habis } \\
\text { Pakai }\end{array}$ & $925.500,00$ & $137.000,00$ & $788.500,00$ \\
\hline Persediaan Alat Tulis Kantor & $225.000,00$ & $137.000,00$ & $137.000,00$ \\
\hline Persediaan Cetak & $700.500,00$ & 0,00 & 0,00 \\
\hline Persediaan Barang Lainya & 0,00 & $3.400 .000,00$ & $3.400 .000,00$ \\
\hline $\begin{array}{l}\text { Persediaan Cetak Blangko } \\
\text { Surat Berharga }\end{array}$ & & $3.400 .000,00$ & $3.400 .000,00$ \\
\hline ASET TETAP & $1.436 .948 .118,97$ & $684.027 .964,77$ & $752.920 .154,20$ \\
\hline Peralatan dan Mesin & $2.176 .962 .766,00$ & $1.541 .413 .044,00$ & $635.549 .722,00$ \\
\hline
\end{tabular}
44.787.550 dengan persentase $99,53 \%$.

\section{Neraca Dinas Kominfo}

Tabel 9. Neraca Dinas Kominfo Tahun 2019 


\begin{tabular}{|c|c|c|c|}
\hline \multicolumn{4}{|c|}{$\begin{array}{c}\text { PEMERINTAH KABUPATEN SOLOK } \\
\text { NERACA DINAS KOMUNIKASI DAN INFORMATIKA } \\
\text { KABUPATEN SOLOK } \\
\text { Per } 31 \text { Desember Tahun } 2019 \text { dan Tahun } 2018\end{array}$} \\
\hline Perlatan dan Mesin & 2.176.962.766,00 & $1.541 .413 .044,00$ & $635.549 .722,00$ \\
\hline Peralatan dan Mesin & $2.176 .962 .766,00$ & $1.541 .413 .044,00$ & $635.549 .722,00$ \\
\hline Gedung dan bangunan & $80.000 .000,00$ & $80.000 .000,00$ & 0,00 \\
\hline Gedung dan bangunan & $80.000 .000,00$ & $80.000 .000,00$ & 0,00 \\
\hline Gedung dan bangunan & $80.000 .000,00$ & $80.000 .000,00$ & 0,00 \\
\hline Jalan Irigasi dan Jaringan & $8.388 .000,00$ & $8.388 .000,00$ & 0,00 \\
\hline Jalan Irigasi dan Jaringan & $8.388 .000,00$ & $8.388 .000,00$ & 0,00 \\
\hline Jalan Irigasi dan Jaring an & $8.388 .000,00$ & $8.388 .000,00$ & 0,00 \\
\hline Aset Tetap lainnya & 17.497.300,00 & 0,00 & 17.497.300,00 \\
\hline Aset Tetap lainnya & $17.497 .300,00$ & 0,00 & $17.497 .300,00$ \\
\hline Aset Tetap lainnya & 17.497.300,00 & 0,00 & 17.497.300,00 \\
\hline Akumulasi Penyusutan & $(845.899 .947,03)$ & $(945.773 .079,23)$ & $99.873 .132,20$ \\
\hline $\begin{array}{l}\text { Akumulasi Penyusutan Aset } \\
\text { Tetap }\end{array}$ & $(845.899 .947,03)$ & $(945.773 .079,23)$ & $99.873 .132,20$ \\
\hline $\begin{array}{l}\text { Akumulasi Penyusutan Aset } \\
\text { Tetap }\end{array}$ & $(845.899 .947,03)$ & $(945.773 .079,23)$ & $99.873 .132,20$ \\
\hline ASET LAIINYA & $27.630 .000,00$ & $27.630 .000,00$ & 0,00 \\
\hline Aset Lainnya & $27.630 .000,00$ & $27.630 .000,00$ & 0,00 \\
\hline Aset Lainnya & $27.630 .000,00$ & $27.630 .000,00$ & 0,00 \\
\hline Aset Lainnya & $27.630 .000,00$ & $27.630 .000,00$ & 0,00 \\
\hline JUMLAH ASET & $1.465 .503 .618,97$ & $715.194 .964,77$ & $750.308 .654,20$ \\
\hline EKUITAS & $1.465 .503 .618,97$ & $715.194 .964,77$ & $750.308 .654,20$ \\
\hline Ekuitas & 1.465.503.618,97 & 715.194.964,77 & $750.308 .654,20$ \\
\hline Ekuitas & $(3.722 .500 .353,03)$ & $715.194 .964,77$ & $(4.437 .695 .317,80)$ \\
\hline Ekuitas & $1.147 .765 .539,37$ & $715.194 .964,77$ & $432.570 .574,60$ \\
\hline Ekuitas & $1.147 .765 .539,37$ & $715.194 .964,77$ & $432.570 .574,60$ \\
\hline Surplus/Defisit-LO & $4.870 .265 .892,40$ & 0,00 & $4.870 .265 .892,40$ \\
\hline Surplus/Defisit-LO & $4.870 .265 .892,40$ & 0,00 & $4.870 .265 .892,40$ \\
\hline RKPPKD & $5.188 .003 .972,00$ & 0,00 & $5.188 .003 .972,00$ \\
\hline RKPPKD & $5.188 .003 .972,00$ & $715.194 .964,77$ & $4.472 .809 .007,23$ \\
\hline RKPPKD & $5.188 .003 .972,00$ & $751.212 .964,77$ & $4.436 .791 .007,23$ \\
\hline JUMLAH EKUITAS DANA & $1.465 .503 .618,97$ & $715.194 .964,77$ & $750.308 .654,20$ \\
\hline $\begin{array}{l}\text { JUMLAH KEWAJIBAN } \\
\text { DAN EKUITAS DANA }\end{array}$ & $1.465 .503 .618,97$ & $715.194 .964,77$ & $750.308 .654,20$ \\
\hline
\end{tabular}

Sumber : Laporan Keuangan Dinas Kominfo Tahun Anggaran 2019

Aset

Aset Dinas Kominfo terdiri dari asset lancar dan asset tetap. Aset lancar di neraca per Desember 2019 dari dana persediaan adalah sebesar Rp. 925.500,-sedangkan nilai aset tetap 
sejumlah Rp. 2.176.962.766,- yang merupakan penjumlahan dari nilai aset peralatan dan mesin, gedung dan bangunan, jalan, irigasi dan jaringan dan aset tetap lainnya.

\section{Peralatan dan Mesin}

Pada tahun 2018 nilai Aset tetap peralatan dan mesin Dinas Kominfo sejumlah Rp. 1.541.413.044,- jika dibandingkan dengan tahun 2019 aset tetap peralatan dan mesin sejumlah Rp. 2.176.962.766,- yang mengalami penambahan sejumlah Rp. 635.549.722,-. Penambahan aset tetap di tahun 2019 ini berupa :

Tabel 10. Neraca Dinas Kominfo Tahun 2019

\begin{tabular}{|llll|}
\hline NO & ASET & ANGGARAN & REALISASI \\
\hline 1 & Pengadaan Peralatan Kantor & 192.350 .000 & 192.249 .920 \\
2 & Pengadaan Peralatan Rumah Tangga & 29.500 .000 & 29.369 .999 \\
3 & Pengadaan Perlengkapan Rumah Tangga & 1.000 .000 & 1.000 .000 \\
4 & Pengadaan Komputer Desktop & 8.500 .000 & 8.500 .000 \\
5 & Pengadaan Komputer Laptop/Notebook & 88.700 .000 & 88.595 .520 \\
6 & Pengadaan UPS & 14.250 .000 & 14.250 .000 \\
7 & Pengadaan Soud System & 15.000 .000 & 14.993 .000 \\
8 & Pengadaan Televisi & 9.000 .000 & 8.985 .886 \\
9 & Pengadaan LCD Proyektor & 30.000 .000 & 29.470 .900 \\
10 & Pengadaan Local Area Network dan Internet & 45.000 .000 & 44.787 .550 \\
& JUMLAH & $\mathbf{6 3 8 . 8 5 0 . 0 0 0}$ & $\mathbf{6 3 5 . 5 4 9 . 7 2 2}$ \\
\hline
\end{tabular}

\section{Gedung dan Bangunan}

Nilai aset tetap gedung dan bangunan Dinas Kominfo tahun 2019 adalah senilai Rp. 80.000.000,- jika dibandingkan dengan tahun 2018 sebesar Rp. 80.000.000,- tidak terjadi penambahan nilai. Pada tahun 2019 Dinas Kominfo Kabupaten Solok tidak menganggarkan belanja modal pengadaan konstruksi bangunan.Sehingga tidak ada penambahan jumlah Aset Tetap.

\section{Jalan, Irigasi \& Jaringan}

Nilai aset tetap jalan, irigasi dan jaringan Dinas Kominfo Kabupaten Solok tahun 2019 masih sebesar Rp. 8.388.000 dan tahun 2018 juga Rp. 8.388.000 yang artinya tidak terjadi penambahan nilai.

\section{Aset tetap lainnya}

Sampai tahun 2019 tidak terdapat aset tetap lainnya di Dinas Komunikasi dan Informatika Kabupaten Solok, sehingga di neraca per Desember 2019 jumlah aset tetap lainnya adalah sebesar Rp. 0,-. 


\section{Kewajiban}

Pada tahun 2019 tidak ada kewajiban jangka pendek maupun jangka panjang pada Dinas Komunikasi dan Informatika Kabupaten Solok.

\section{Analisis Laporan Arus Kas Dinas Kominfo}

\section{Analisis PAD Dinas Kominfo}

Pendapatan Asli Daerah (PAD) pada Dinas Kominfo berjumlah sebesar Rp. 643.481.068,-. Sedangkan jumlah yang dianggarkan untuk dipungut adalah sebesar Rp. 500.000.000,-. Jumlah tersebut lebih besar dari yang dianggarkan, yaitu mencapai 128,7 \%. Dari hasil tersebut dalam disimpulkan bahwa kinerja Dinas Kominfo sangat baik dengan mencapai target pemungutan PAD lebih dari $100 \%$.

\section{Analisis Belanja Dinas Kominfo}

Berdasarkan tabel 4.1 dapat dilihat bahwa belanja Dinas Kominfo Kabupaten Solok pada Tahun Anggaran 2019 dianggarkan sebesar Rp. 6.068.244.878,- sedangkan terealisasi pada tahun tersebut sebesar Rp. 5.831.485.040,- atau terealisasi sebesar 96,10\%. Walaupun tidak teralisasi 100\% namun secara keseluruhan kinerja Dinas Kominfo dapat dinilai baik dan sudah berjalan dengan efektif karena semua kegiatan dapat terlaksana tanpa kendala selama tahun 2019.

\section{KESIMPULAN DAN SARAN}

Dinas Komunikasi dan Informatika Kabupaten Solok sudah menyajikan laporan arus kas dengan baik dan efektif sesuai dengan Peraturan Pemerintah Nomor 24 Tahun 2005 tentang Standar Akuntansi Pemerintah dimana penyajian laporan tersebut sudah mencantumkan Laporan Realisasi Anggaran (LRA), Neraca, Laporan Arus Kas dan Catatan Atas Laporan Keuangan. Dari Catatan Atas Laporan Keuangan Dinas Komunikasi dan Informatika Tahun 2019, dapat disimpulkan bahwa kinerja Dinas Kominfo sudah berjalan dengan baik dengan pencapaian Pendapatan Asli Daerah (PAD) Dinas Kominfo mencapai angka yang lebih dari $100 \%$ dan secara umum sasaran-sasaran strategis yang ditetapkan dalam Rencana Kerja Tahunan Tahun 2019 telah dapat dipenuhi, meskipun rencana tersebut belum sepenuhnya tercapai $100 \%$.

\section{REFERENSI}

Agresti, Allan. 2002. Categorical Data Analysis. New York: John Wiley and Sons.

Aji, Candra Zebeh. 2012. Berburu Rupiah Lewat Game Online. Yogyakarta: Bounabooks.

Arikunto, Suharsimi. 2010. Prosedur Penelitian Suatu Pendekatan Praktik. Jakarta: PT Rineka Cipta.

Arikunto, Suharsimi. 2003. Dasar-dasar Penelitian Suatu Pendekatan Praktek. Jakarta: PT Bumi Aksara. 
Badudu dan Zain. 2005. Pengertian Pengaruh Kecanduan Game Online pada Remaja. htpp://dspace. widyatama.ac.id/bitstream/handle/10364/1037/bab2.apdf?sequence $=4 .[14$ Agistus 2020].

Beranuy, M., Carbonell, X., \& Griffiths, M. D. 2013. A Qualitative Analysis Of Online Gaming. International Journal of Mental, 11, 149-161.

Brian, D., \& Wiemer-Hastings, J. (2005). Addiction To The Internet And Online Gaming. Journal cyberpsychology and behavior, 8, 2 .

Budiman, H. P. 2009. Dunia Mewaspadai Game Online, Indonesia Kapan?. Psikologi Plus (Majalah). Vol I Edisi Maret. 39-43.

Gunarsa, S.D., dan Gunarsa, Y.S.D. 1998. Psikologi Perkembangan Anak dan Remaja. Jakarta: BPK Gunung Mulia.

Hurlock, Elizabeth B. 1980. Psikologi Perkembangan. Erlangga : Gelora Aksara Pratama.

Hosmer and Lemeshow, W. 1989. Applied Logistic Regression. Canada: A Wiley Interscience Publication.

Kartasasmita, Sandi dan Nirmala, Carana. 2012. Gambaran Mindfulness pada Remaja yang Kecanduan Bermain Game Online. https://www.researchgate.net/publication/264550255. [14 Agistus 2020].

Kusumawati, Rosi., Irna Aviani, Yolivia., \& Molina, Yosi. 2017. Perbedaan Tingkat Kecanduan (Adiksi) Games Online Pada Remaja Ditinjau Dari Gaya Pengasuhan. Journal psikologi, 89.

Makridarkis, Spyros. 1999. Metode dan Aplikasi Peramalan. Jakarta : Binarupa Aksara.

Masya, Hardiyansyah., \& Candra, Adi Dian. 2016. Faktor-faktor yang Mempengaruhi Perilaku Gangguan Kecanduan Game Online Pada Remaja Peserta Didik Kelas X di Madrasah Aliyah Al Furqoon Prabumuluh Tahun Pelajaran 2015/2016. Journal Bimbingan dan Konseling, 03, 153-159.

Montgomery, Douglas, Peck, Elizabeth, dan Vining, Geoffrey. 2006. Introduction to Linear Regression Analysis, Fourth Edition, USA: Wiley-Intersicience Publication.

Monks, F. J, Knoers, A.M.P, \& Haditono, S.R. 1982. Psikologi Perkembangan: Pengantar Dalam Berbegai Bagiannya. Yogyakarta : Gadjah Mada University Press.

Muhidin, Sambas Ali, dkk. 2007. Analisis korelasi, Regresi dan Jalur dalam Penelitian. Bandung: Pustaka Setia.

Rini, A. 2011. Menanggulangi Kecanduan Game Online Pada Anak. Jakarta. Pustaka Mina.

Saputra, Rahmadi. 2016. Hubungan Kecanduan Game Online Clash of Clans Terhadap Prestasi Akademik Mahasiswa Ilmu Komunikasi Fakultas Ilmu Sosial dan Politik Univesitas Riau. 
JOM FISIP Vol. 3 No. ,. 5-6

Singarimbuan, Masri dan Effendi, Sofian. 2011. Metode Penelitian Survai. Jakarta: PT Pustaka LP3ES Indonesia.

Sugiyono. 2012. Memahami Penelitian Kualitatif. Penerbit CV. Alfabeta. Bandung.

Surya, Yuyun W.I, 2002, Pola Konsumsi dan Pengaruh Internet sebagai Media Komunikasi Interaktif pada Remaja (Studi Analisis Persepsi pada Remaja di Kotamadya Surabaya), Lembaga Penelitian Universitas Airlangga, Surabaya.

Suryabrata, Sumadi. 2012. Metodologi Penelitian. Jakarta: PT Raja Grafindo Persada.

Susanti, Y. 2008. Ketergantungan pada internet: game online, Video games dan sejenisnya. Anima: Indonesian psychological journal, 23, 180-183.

Umar, Husein. 2005. Metode Penelitian Untuk Skripsi dan Tesis Bisnis. Jakarta: PT Raja Grafindo Persada.

Yanto, Riki, 2001. Pengaruh Game Online Terhadap Perilaku Remaja. Skripsi. Padang: Fakultas Ilmu Sosial dan Ilmu Politik Universitas Andalas.

Yuniar, S. 2008: Ketergantungan Pada Internet : Game Online, Video Game, dan sejenisnya. Anima : Indonesia Psychological Journal. Vol. 23, No.2 (180-183).

Ziqri, Aulia. 2010: Faktor-faktor yang Mempengaruhi Partisipasi Politik Masyarakat Kecamatan Koto Tangah dalam Pelaksanaan Pemilihan Walikota dan Wakil Walikota Padang Tahun 2013 Menggunakan Analisis Regresi Logistik. Tugas Akhir. Program Studi Statistika Jurusan Matematika FMIPA UNP. 